\title{
DETERMINANT ANALYSIS OF BILATERAL TRADE BETWEEN INDONESIA AND YEMEN DURING THE PERIOD 1990-2015: A GRAVITY MODEL APPROACH Sulthon Sjahril Sabaruddin*1
}

${ }^{1}$ Indonesian Embassy in Sana'a Salalah, Sultanate of Oman

\begin{abstract}
This study examines the factors that influence the performance of bilateral trade between Indonesia and Yemen. In conducting the study, the authors use the conventional bilateral trade model is modified gravity model of international trade approach by using multiple regression analysis with Ordinary Least Square meth$o d$. The analysis finds that the three independent variables that significantly affect the value of bilateral trade between Indonesia-Yemen is the GDP of Yemen, political uncertainty and security in Indonesia, as well as the presence of Indonesian Representative in the Republic of Yemen. While other independent variables namely Indonesia's GDP and political uncertainty and security in Yemen, based on the conclusions statistically, the two independent variables do not yet have enough evidence to say that the GDP of Indonesia and political uncertainty and security in Yemen significantly affect bilateral trade between Indonesia-Yemen. This trade gravity model previously passed testing assumptions multiple regression analysis with hypothesis testing and the accuracy of the model.
\end{abstract}

Keywords: Economic diplomacy, bilateral trade, gravity model, multiple regression Ordinary Least Square

JEL Classification: F14, F15, F17

To cite this document: Sabaruddin, S. S., (2016). Determinant Analysis of Bilateral Trade Between Indonesia and Yemen During The Period 1990-2015: A Gravity Model Approach. JDE (Journal of Developing Economies), 1(2), 107-121

\section{Introduction}

In the modern era, diplomatic relations between Indonesia and Yemen officially has existed since North Yemen give recognition to the independence and sovereignty of the Republic of Indonesia on May 3, 1948. North Yemen is one of the first Arab countries that recognize the Unitary Republic of Indonesia (NKRI). However, relations between the two countries has existed for centuries, long before the two countries stood. Both countries have an emotional connection, and historically, particularly those related to the history of thespread of Islam to Indonesia in the past. The Nation of Yemen from Hadhramaut region, southern Yemen has come to the archipelago since the $11^{\text {th }}$ century (some have claimed since the $9^{\text {th }}$ century) for trade and spread the religion of Islam. According to some sources, it is estimated there are about 8 million citizens of Indonesia Yemeni and most of them work in the field of trade and some of them have become an important figure in Indonesian politics asMinisters, Ambassadors and members of Parliament. With the approximately 8 million Yemenis in Indonesia is a capital and a solid foundation to build economic and cultural ties between the two countries are brothers.

Since the unification of North Yemen and South Yemen became the Republic of Yemen on May 22, 1990, the Yemeni government changed the status of the Consulate General

JDE (Journal of Developing Economies) p-ISSN: 2541-1012; e-ISSN: 2528-2018 DOI: http://dx.doi.org/10.20473/jde.v1i2.3296

Open access under a Creative Commons Attribution 4.0 International

(CC-BY) 
of South Yemen in Jakarta became the Embassy of the Republic of Yemen. Whilethe Office of Indonesian Republic Embassy in Sana'a determined based on PresidentialDecree No. 12 of 1992 dated February 12, 1992, and officially opened on 16 November1992. During the period 1990-2016, the two established diplomatic relations is quite intense and friendly. Relations between the two countries in various fields such as politics, economy, social and culture is constantly increasing.

In the political sphere, the close relations between the two countries is also characterized by reciprocal visits of high officials of both countries. Noted Indonesian President Abdurrahman Wahid made an official visit to Yemen on 21-22 February 2001 which is a return visit of President of Yemen Ali Abdullah Saleh to Indonesia in February 1998. Meanwhile, Indonesian Vice President Hamzah Haz ever visit to Yemen 13-15 September 2003. Instead, Yemeni President Abdu Rabbu Mansour Hadi has made a visit to Jakarta to attend the Extraordinary Summit $5^{\text {th }}$ Organization of Islamic Conference (OIC) on 6-7 March 2016 in Jakarta. Previously, Abdu Rabbu Mansour Hadi never been to Indonesiain late August 2002, but at that time as Vice President of Yemen. On February 28, 2009, Yemeni President Ali Abdullah Saleh has also made a visit to Indonesia in order to attend the $5^{\text {th }}$ World Islamic Economic Forum (WIEF) which took place on March 2-3, 2009 in Jakarta.

In the economic field, during the period 1990-2015 economic relations between the two countries continues to increase. In its development, it was noted that the bilateral relations in the economic field between Indonesia and Yemen continue to grow. The first agreement in the field of economics began when the two sides signed the Agreement on Cooperation Indonesia - Yemen on Economy, Trade, Science and Engineering in 1994. Furthermore, a wide range of economic cooperation agreements have been established between the two countries, namely:

1. Implementation Program between the Ministry of Agriculture of the Republic of Indonesia and the Ministry of Agriculture and Irrigation of the Republic of Yemen on the Cooperation of Livestock and Agriculture (February 4, 2009, Sana'a).

2. Memorandum of Understanding between the Government of the Republic of Indonesia and the Government of the Republic of Yemen on Agricultural Cooperation (August 10, 2005, Yogyakarta).

3. Memorandum of Understanding between the Batam Industrial Development Authority (BIDA), the Republic of Indonesia and the Free Zone Aden, Republic of Yemen on Cooperation-Free Zone (August 10, 2005, Yogyakarta).

4. Memorandum of Understanding between the Government of the Republic of Indonesia and the Government of the Republic of Yemen on Cooperation for Trade Promotion (August 10, 2005, Yogyakarta).

5. Memorandum of Understanding between the Government of the Republic of Indonesia and the Government of the Republic of Yemen on Health Sector Cooperation (August 10, 2005, Yogyakarta).

6. Memorandum of Understanding between Bank Indonesia and the Central Bank of Yemen on Cooperation and Information Exchange (September 24, 2003, Sana'a).

7. Trade Agreement between the Government of the Republic of Indonesia and the Government of the Republic of Yemen (February 20, 1998, Jakarta).

8. Agreement between the Government of the Republic of Indonesia and the Government of the Republic of Yemen on the Promotion and Protection of Investments (February 20, 1998, Jakarta).

9. Memorandum of Understanding between the Government of the Republic of Indo- 
nesia and the Government of the Republic of Yemen on the Establishment of a Joint Commission for Economic Cooperation, Science, Engineering and Commerce (February 20, 1998, Jakarta).

10. Agreement between the Government of the Republic of Indonesia and theGovernment of the Republic of Yemen on Economic Cooperation, Trade, Science andEngineering (January 24, 1994, Sana'a)

In the field of trade, during the period 1990-2015 Indonesia - Yemen trade relations have been increasing quite rapidly. In 1990, bilateral trade amounted to only US \$10.46 million, and now in 2015 the trade volume between the two countries amounted to US \$ 89.30 million. In 2013, bilateral trade reached a peak of US $\$ 159.38$ million. As Indonesia's main exports to Yemen include: palm oil, fishery products, paper products, motor vehicle tires, and motor vehicles. Meanwhile, the main commodities imported from Yemen are fishery products.

During the period 1990-2015, although economic relations between the two countries has increased, but in its development, there are some big challenges (or referred to as disturbance variables) faced by both countries. A number of disturbance variables are: Yemen civil war (1994), Indonesia's economic crisis (1998/99), the Arab Spring (2011), the occupation of the capital Sana'a by Al-Houthi militias (21 September 2014), air strikes led coalition troops Saudi Arabia (March 25 2015), the Agreement Embassy in Sanaa left Sana'a (March 30, 2015), as well as the explosion near the Indonesian Embassy in Sanaa (20 April 2015) became a factor that allegedly affect performance relationship economies of both countries, one of which seems to have an impact on trade relations between the two countries (Graph 1).

Graph 1: Indonesia - Yemen Trade Development Years 1990 - 2015

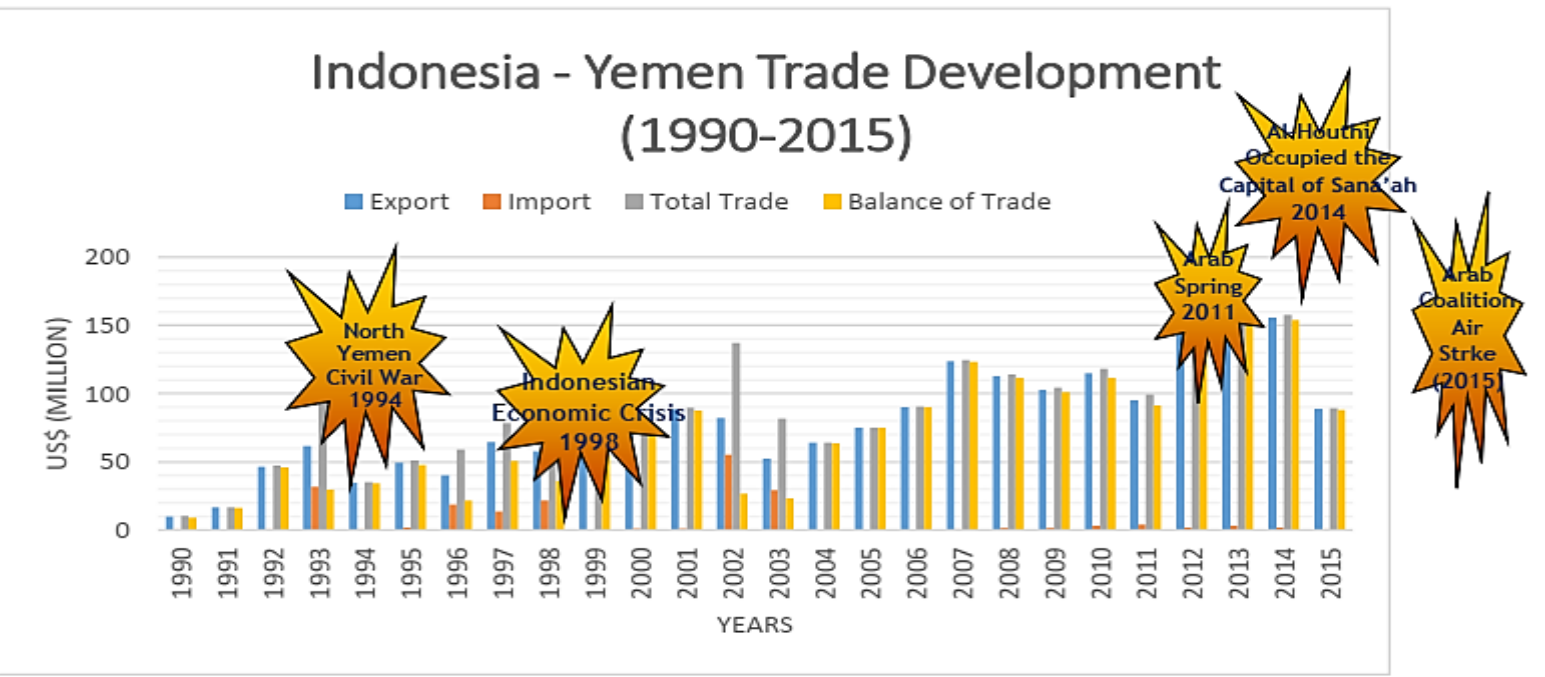

Source: United Nations COMTRADE and the Ministry of Trade (2016)

In regard to economic relations between Indonesia and the Yemeni, Indonesian Embassy in Sana'a continues to perform a series of economic diplomacy to contribute to the Indonesian Government's efforts to realize the goals and targets in an increase in exports, investment, tourism and development cooperation. Embassy in Sana'a assessing political and security developments in the Republic of Yemen which until now is still uncertain and the existence Embassy in Sana'a in Salalah (outside the country of accreditation) is a challenge for the Indonesian Embassy in Sana'a in running a series of diplomatic efforts and economic activity in Republic of Yemen.

Indonesia and Yemen have considerable economic potential. The layout of the two countries is strategically contribute to improving the economic potential of this. Indonesia is located between two major continents (Asia and Australia) and two oceans (Indian and Pacif- 
ic). While Yemen is located at the entrance to the Red Sea leading to the Suez Canal andthe good to the countries in East Africa and the Horn of Africa countries. In addition, both countries have mining products (mainly oil) and the other agricultural products.

The Republic of Yemen is one country in the Arab world that have economic potential and a considerable market potential for Indonesia if the economic opportunities can be put to good use. On the other hand, Yemen is one of the Least Developed Countries (LDCs) of Gross Domestic Product (GDP) per capita (2015), the lowest in the Middle East region which is around US $\$ 1,235$. Political and security conditions are not conducive since mastered the capital Sana'a by militia Al-Houthi 21 September 2014 and its peak earlier whenthe coalition forces led by Saudi Arabia to intervene with air strikes in Yemen on March 25, 2015 and have a significant impact on Yemen's economy. International Monetary Fund (IMF) estimates Yemen's economic growth in 2015 declined dramatically by -28 per cent, and this makes Yemen as the country with the worst economic performance in 2015.

However, behind the many problems being faced by the people of Yemen is, in fact the country still has economic potential and a considerable market if Indonesia keen to take advantage of existing opportunities. First, since the unification of Yemen in 1990 ago, Yemen is a trading partner of Indonesia which always gives the advantage of foreign exchange for Indonesia with a record trade surplus in the Indonesian side. In 2012, Indonesia recorded a trade surplus of US $\$ 155.13$ million. The trade value of the surplus is the highest in history for Indonesia.

In addition, the amount of space in the Yemeni market can also be seen from the total value of foreign trade of Yemen itself. In 2014, the total value of foreign trade of Yemen reached US \$14.4 billion and a net importer countries amounted to US \$ 9.6 billion. Yemen relies heavily on commodity imports to meet its domestic needs, which is at least about 80 percent of needs met from other countries. The items needed consist of various types, rangingfrom consumer goods, household goods, to building materials, equipment and machinery (capital goods).

The existence of Yemen as a net importer of these, should be used as best as possible to boost the export of Indonesian products to Yemen. Furthermore, the import tariff Yemeni government imposes relatively not large. Import tariff (MFN applied simple average tariff) of agricultural products amounted to 10:44 percent. As for the manufacturing product, tariff by 7 percent. Seeing that picture, can be illustrate that is still open space and a big opportunity for Indonesia to enhance its trade volume with Yemen.

Furthermore, the value of bilateral trade between Indonesia - Yemen today is still far below its potential and should be increased in the future. As an illustration, in Yemen trade relations with Indonesia's neighboring countries such as Thailand and Malaysia recorded more than Indonesia. In 2015, trade relations Yemen - Thailand reached (US \$ 234.38 million. As an illustration, in the same year Indonesia - Yemen trade value of US \$ 89.30 million.

Second, the number of Yemen's population reached 26 million people (as of January 2016) and is the most populous country in the Arabian Peninsula. The magnitude of this population indicates that Yemen has a fairly large market. Third, in terms of economic power, Yemen's GDP reached US $\$ 35.95$ billion (2014) to make this country as all world's93 largest economies.

Fourth, the Republic of Yemen has been a member of all 160 WTO Ministerial Conference on 9th December 4, 2013 in Bali. And on April 28, 2014, the Yemeni Parliament has ratified the WTO accession protocol. Therefore, the estimated future Yemen will reorganize the relevant regulations of free trade and open the chance for Indonesia to explore the possibility of Indonesia - Yemen Free Trade Agreement (FTA) or a Preferential Trade Agreement (PTA).

And fifth, the Embassy in Sana'a (2015) assess when viewed from the trading volume 
Yemen and Indonesia, it appears that there is a positive trend for Indonesian products to be marketed to consumers in Yemen. Although China and Malaysia quite aggressively markets its products through various trade fairs in Yemen as well as through other trade channels, Yemen consumers are still attracted to Indonesian products. One factor that interest is, in general, Indonesia is still considered qualified products.

Seeing the potential market opportunities and the economy, Yemen should earn a spot as one of the 'target' in Indonesia's economic diplomacy. The conflict in Yemen are still ongoing to this day and the position of the switch Embassy in Sana'a, Salalah, Oman, for the time is certainly a significant impact on economic cooperation between Indonesia and Yemen. But on the other hand, there is a chance of hope in 2016 when the war ended and Yemen reconstruction program began to be implemented. Yemen reconstruction will requirea lot of goods and services required for the construction. Economic potential and market opportunities in Yemen need to be explored in greater depth so that the results of Indonesia's economic diplomacy efforts can provide economic benefits for both countries targeted in the future.

According to the vision and mission of the program at Joko Widodo (Jokowi) era, in the period from 2015 to 2019, one of the top priority program in foreign policy is tostrengthen the performance of Indonesia's economic diplomacy with the aim to participate in promoting economic growth and improve the welfare of the Indonesian people. One important aspect of economic diplomacy is to improve trade relations (particularly encouraging exports Indonesia). Export is one important source of foreign exchange for the economy of Indonesia and as mandated in the National Medium Term Development Plan 2015-2019.

\section{Literature Review}

As mandated in the National Medium Term Development Plan 2015-2019 (RPJMN 2015-2019), the performance success of Indonesia's economic diplomacy can be seen from indicators of the value of trade, investment, the number of tourist arrivals (tourists) tolndonesia, as well as income transfers or remittances. Therefore, it can translate that success Indonesia - Yemen performance and economic diplomacy Embassy in Sana'a in Yemen Republic state accreditation can be seen through the indicator of the value of bilateral trade (especially exports), Yemen investment in Indonesia, the number of foreign tourists visiting Yemen to Indonesia, as well as income transfers or remittances Indonesia from Yemen who are all sources of foreign exchange.

Economic diplomacy can be defined as a systematic attempt run a country by leveraging a number of strengths and economic resources owned in order to achieve its foreign policy objectives. Therefore, economic diplomacy Embassy in Sana'a can be translated as a series of economic diplomacy efforts undertaken Embassy in Sana'a to help enhance economic relations between Indonesia and Yemen with available budget and personnel resources. In the implementation of economic diplomacy, recorded in severalinternal reports released by the Embassy in Sana'a and the Ministry of Foreign Affairs explained that the political uncertainty and security situation in Yemen seems to have a big impact on the performance of economic relations between Indonesia and Yemen.

Based on the above it becomes important to do the assessment in detail the factors that influence the performance of Indonesia's economic diplomacy. In this case, economic diplomacy Embassy in Sana'a in the country of accreditation Republic of Yemen. Expectedby identification of variables more concretely affecting the performance of economic diplomacy at the Embassy in Sana'a, through the results of this study further expected to provide input and suggestions policies that are beneficial to the Indonesian Embassy in Sana'aand the Ministry of Foreign Affairs Centre, especially in addressing and taking diplomatic policy Indonesia's economy in the Republic of Yemen is more effective and targeted. In addition, this study is expected to also be one of the references for Indonesian representatives in other overseas in order to more concretely measure any factors that influence the performance of the Indone- 
sian representatives in conducting economic diplomacy in countries of accreditation.

Identify and evaluate the factors that influence the trade relations between Indonesia and Yemen, one of the approaches that can be used economic model is the gravity model, a model of a conventional bilateral trade. Gravity model in the study of international trade was first introduced by Tinbergen (1962). The basic equations of gravity models in international trade are as follows:

$$
F_{i j}=G \frac{M_{i} M_{j}}{D_{i j}^{2}}
$$

Where (FIJ) is "flow" from the point of origin to the destination point i j. or, (FIJ) is the total volume of interaction between $\mathrm{i}$ and $\mathrm{j}$ (the number of streams in both directions: $\mathrm{F} \mathrm{ij}=+\mathrm{Fji}$ $\mathrm{FIJ}$ ); (Mi and $\mathbf{M j}$ ) are the measures of the economy of the two locations; (Dij) is the distance between the two locations. If $F$ is measured as the flow of money (for example, exports), then $M$ is usually theGross Domestic Product (GDP) in an economy, If $F$ is the flow of people, then $M$ is the populations of both locations.

Bergstrand (1985) developed a model of the gravitational equations in the study of bilateral trade. The equation describes the volume of exports between the two trading partners as a function of the Gross Domestic Product (GDP) and the distance between them.

$$
P X_{i j, t}=\alpha_{0}\left(Y_{i, t}\right) \beta_{1}\left(Y_{j, t}\right) \beta_{2}\left(D_{i j}\right) \beta_{3}\left(A_{i j}\right) \beta_{4} \varepsilon_{i j}
$$

Where (PXij, t $\mathbf{t}$ describe the volume of exports from country $i$ to country $j$, at time $t ;(\mathbf{Y i}, \mathbf{t})$ describe the GDP of the country $i$, at time $t ;(Y j, t)$ describe the GDP of the country j, at time t; (Dij) describes the geographical distance (in miles) between country i to country j; (Aij) describes the factors that may affect bilateral trade between country $i$ to country $j$.

Gravity model in the study of trade continues to experience a lot of developments and modifications by many previous investigators. One of them is relevant in this study is a modified gravity model of trade by Rose (2007). Rose (2007) adds a variablepresence of representatives (embassies and consulates) in equation gravity model of trade. According to Rose (2007), in the past the foreign missions (foreign mission) have a strategic role as a source of information and given big authority in taking a decision on the policy of the state accreditation.

But along with the development of information, communication and technology (ICT) and communication costs become more affordable, it is a lot of information about foreign countries that can be obtained quickly and at low cost. So in the current era, the role of representative missions abroad seems increasingly eroded. Now, many Ministry of Foreign Affairs as the United States, United Kingdom, Canada, and Australia emphasize one of the priority role of foreign missions is to promote exports. In a study by Rose (2007) explains that the presence of overseas representatives estimated positively related to exports. The existence of the foreign missions are expected to increase approximately 6-10 percent of the export value.

In Indonesia, the Ministry of Foreign Affairs (Foreign Ministry) through Indonesian Missions abroad who are at the forefront of Indonesia's diplomacy abroad (in this case, economic diplomacy Indonesia) with the Indonesian Trade Promotion Center (ITPC, Ministry of Trade) claims to be the agent of export promotion, so that the performance of the Indonesian representatives abroad is measured by the amount of the value of bilateral trade between Indonesia (especially export Indonesia) in the country of accreditation. But now that often the question is not whether the Indonesian representatives abroad are believed to have a role as an agent of export promotion, but whether the existence of Indonesian representatives abroad shown to effectively improve Indonesia's trade relations in the country of accreditation, particularly exports of Indonesia.

Yakop \& van Bergeijk (2011), in his study with the same method with the Rose (2007), 
but with a range of years and a number of different countries found that the presence of foreign missions is not relevant in increasing export volume among member Organization for Economic Co-operation and Development (OECD). However, the presence of foreign missions OECD in developing countries has a significant influence on bilateral trade relationsdue to the foreign missions OECD can facilitate imports and encourage exports.

Studies on Indonesia bilateral trade using a gravity model approach has been quite a lot done in previous research. For example, Yuniarti (2007) especially within recurrent neural network (RNN analyze the factors affecting Indonesia's bilateral trade with the gravity model approach. The analysis showed that bilateraltrade between Indonesia with 10 major trading partners, positively influenced by variables national income trading partner of both exporters and importers, importers population, similarsize of the economy. While the distance with trading partners have negative effect. The difference in relative factor endowment, and membership in a free trade area has no effect on bilateral trade.

In another study, Sarwoko (2009) in the analysis of Indonesia's bilateral trade with the 12 major trading partners find that the Indonesian trade is positively influenced by economic measures that GDP and GDP per capita of the country's main trading partners, and isnegatively affected by the geographical distance between Indonesia and countries of major trading partners. GDP and GDP per capita of Indonesia has no effect on trade.

\section{Research Methodology}

This study will analyze the factors that influence the performance of bilateral trade between the Yemen. In conducting the study, the authors use the model of bilateral trade conventional approach is modified gravity model of international trade. The formulation of the model is the first step in studying the relationships between variables. Based on earlier research, the approach used to estimate the gravity model is the first model should be linear with the change to a log-linear. Thus, the basic gravity equation model of trade that has been modified and transformed in the form of a linear equation is as follows:

$$
P X_{i j} L n_{t}=\alpha_{0}+\beta_{1} \ln Y_{i, t}+\beta_{2} \ln Y_{j, t}+\beta_{3}\left(p l i_{t}\right)+\beta_{4}\left(p l j_{t}\right)+\beta_{5}(F M T)+\varepsilon
$$

Where (PXij, $\mathbf{t}$ ) describe Indonesia's trade volume to Yemen; $(\mathbf{Y i}, \mathbf{t})$ describe the GDP of Indonesia, at time $t ;(\mathbf{Y j}, \mathbf{t})$ describe the GDP of the country of Yemen, at time $t$; (PII, $\mathbf{t})$ describe the situation of political instability and security of Indonesia, at time t; (PIJ, t) describe political instability and security situation in Yemen, at time t; (Fmij) describe the existence of Indonesian state representative in the country of Yemen.

Based on these factors suspected to affect bilateral trade between Indonesia andYemen, then that becomes the hypotheses and initial assumptions are:

1. Indonesia's GDP expected positive effect on trade between Indonesia and Yemen.

2. GDP Yemen expected positive effect on trade between Indonesia and Yemen.

3. The political uncertainty and security situation in Indonesia is expected to negativelyaffect trade between Indonesia and Yemen.

4. The political uncertainty and security situation in Yemen is expected to negativelyaffect trade between Indonesia and Yemen.

5. The presence of representatives of Indonesia in Yemen expected positive effect ontrade between Indonesia and Yemen. isas follows:

As for the definition of each variable in the equation gravity model of bilateral trade

1. Volume of trade between Indonesia and Yemen is the value of bilateral trade be- 
tweenIndonesia and Yemen and is expressed in units of US \$ (US dollars).

2. Indonesia's GDP is a measure of the magnitude of the Indonesian economy and theeconomy is expressed in units of US \$ (US dollars).

3. Yemen's GDP is a measure of the economic scale of Yemen's economy and isexpressed in units of US \$ (US dollars).

4. The political uncertainty and security situation in Yemen is how big influence onbilateral trade between Indonesia and Yemen.

5. The political uncertainty and security situation in Indonesia is how big influence onbilateral trade between Indonesia and Yemen.

In this study, the standard equation model of gravity is modified by adding independent variables FMij, where the Indonesian representatives in the Republic of Yemen (foreign mission), political uncertainty and security in Yemen and Indonesia (PII, t and PIJ, t)and not the inclusion in the model equations of gravity by reason of geographical distance between the two countries has not changed over the period 1990-2015. The addition of independent variables Fmij, based study of Rose (2007). In addition, consideration also explained the importance of political factors and safety in the performance of economic diplomacy which is run by a foreign representative in the country of accreditation.

Dummy variables will be used to determine the qualitative relationship between independent variables with the dependent variable (Hanke et al., 2003). Dummy variables used in the model equations of gravity is the political uncertainty and security situation in Indonesia and Yemen $\left(\mathrm{PI}_{\mathrm{i}, \mathrm{t}}\right.$ dan $\mathrm{PI}_{\mathrm{j}, \mathrm{t}}$ variable). Where $\mathrm{D}=0$ is no political uncertainty and security in Indonesia and Yemen, and' $D=1$ is the presence of political uncertainty and security in Indonesia and Yemen. Gravity model equation above is a multiple regression statistical model. The regression model consisting of more than one independent variable is called multiple regression model. In multiple regression analysis, it is sometimes necessary todetermine whether the dependent variable associated with an independent variable when qualitative factors affect the state (Hand, 2008). This relationship can be resolved by the formation of a dummy variable that takes a value of 0 and 1 .

Based on previous studies, gravity models are expected in the form of a log-linear. So,quantitative analysis used in this study is an econometric model with OLS (Ordinary Least Square) or the principle of ordinary least squares method. Through OLS coupled with the technique of multiple regression analysis of time series with cross section data.

In multiple regression analysis several assumptions have to be tested. With these assumptions are already fulfilled, then the least squares estimator in a class not biased estimator has minimum variance is Best Linear Unbiased Estimator (BLUE). Testing assumptions in multiple regression analysis performed because it is based on several assumptions that must be fulfilled, namely normality test, homoscedasticity test, multicollinearity test, and autocorrelation test. In addition, prior to the tests the assumption, also conducted an evaluation whether the model used is good or not (Goodness of Fit), using statistical testing criteria is the coefficient of determination $\mathrm{R}^{2}$, and t-test.

The analytical method used is quantitative method. Quantitative methods used in this research is multiple regression analysis in a single equation using the gravity model. This model is used to analyze the factors affecting the performance of trade between Indonesia and Yemen. Data processing starts from the grouping data, calculations and tabulated as needed. Quantitative data were processed using the Excel computer program package and STATA 12 and then output the results of the computer interpreted.

This study used secondary data, time series and cross section data. Time series data in- 
clude annual data on indicators of economic diplomacy during the period 1990-2015 covering bilateral trade between Indonesia and Yemen. The trade data was obtained from the Ministry of Trade. The economic growth and the GDP of Indonesia and Yemen data obtainedfrom the Badan Pusat Statistik (BPS), Bank Indonesia (BI) and the World Bank. While data security and political uncertainty (particularly in Yemen) as well as the presence of the Indonesian Embassy in Sana'a in the state accreditation (Republic of Yemen) obtained from the various reports released by the Embassy in Sana'a.

\section{Results}

\section{Hypothesis Testing and Accuracy Model (Goodness of Fit)}

First of all the models that are being analyzed, must first be examined whether the quality is good. Hypothesis testing is done to see the real effect of selected variables to the variables studied. Based on regression analysis, then the tests include the following:

\section{t-Test}

This test is intended to determine whether the independent variable partially significant effect or not on the dependent variable. The t-test on the results of the regression analysis the factors affecting bilateral trade between the Yemeni obtained variables significant at the level of five percent (significant at the 95 percent confidence level) of the bilateral trade between the Yemen. The variables that affect real GDP is Yemen, political uncertainty and security situation in Indonesia, as well as the presence of the Indonesian Embassy in Sana'a in Yemen. It can be seen from the value of $p>|t|$ less than 0.05 so that theindependent variables significantly influence the dependent variable. And vice versa, Indonesia's GDP variable and uncertain political and security situation in Yemen has no significant effect on bilateral trade between Indonesia and Yemen.

\section{Coefficient of Determination}

The coefficient of determination $\mathrm{R}^{2}$ shows the ability of the model to explain the relationship between the independent variables and the dependent variable. The $R^{2}$ will always be between 0 and 1 . The closer to 1 , meaning the greater the ability of independent variables to explain (influence) to the dependent variable. In regression analysis the factors that affect the value of bilateral trade between Indonesia - Yemen coefficient of determination $\mathrm{R}^{2}$ of 0.832 , meaning the regression line can be explained by 83.2 percent. Value of 0.832 (or 83.2 percent) indicated that the independent variables in the model is able to explain the variation in Indonesia - Yemen bilateral trade amounted to 83.2 percent. Whilethe remaining 16.8 percent is explained by other variables outside the model.

\section{Testing Assumptions}

Testing assumptions in multiple regression analysis performed because it is based on several assumptions that must be fulfilled, namely normality test, homoscedasticity test, multicollinearity test, and autocorrelation test. If there are (at least one) of the assumptions in the regression model can not be fulfilled by the regression function is obtained, then the truth of the model prediction is doubtful. On the contrary, if all of the assumptions underlying the model are fulfilled, then a regression function obtained from the calculation of estimators with the method of ordinary least squares (OLS) regression coefficient is Best Linear Unbiased Estimator or not biased estimator best linear (BLUE).

\section{Normality Test}

One of the tests made in the regression equation to test whether the values of $Y$ normally distributed at each value of $\mathrm{X}$ is the normality test. Testing normality can be done with the methods used to test the normality of the data is the method of KolmogorovSmirnov. Normality test is done using the Kolmogorov-Smirnov (attachment). The test results on the 
level of five percent is obtained throughout the $p$ value $>0.05$, so it can be concluded that the normality assumption already fulfilled.

\section{Homoscedasticity Test}

This assumption basically states that the values of $Y$ (the dependent variable) vary in the same unit, both for the value of $X$ (independent variable) high and a low $X$ value. If the assumptions are not being fulfill, then it can be said irregularities. Cameron Trivedi using IM-Test Heteroskidastity $p$ value of 0.8982 . This value is greater than 0.05 . Thus, it can be concluded that there is no heteroscedasticity. The test results showed homoscedastisity assumptions have been fulfilled.

\section{Multicollinearity Test}

The linear relationship between two or more independent variables called multicolinearity. One way to measure the strength of multicolinearity is the variance inflationfactor or Variance Inflation Factors (VIF). Based on regression analysis found that VIF (attachment) on each independent variable is less than 10 . This shows that there is nomulticollinearity. Thus, the test results can be concluded that non multicolinearity assumptions are being fulfill.

\section{Autocorrelation}

One of the assumptions in the model using OLS is no autocorrelation. Autocorrelation is the relationship between the residual of the observation by other observation residual. Autocorrelation test used in Durbin test (Durbinalt), the serial test every possible error that occurred. Durbin test is one test that is widely used to determine whether there is autocorrelation. Regression analysis found that Prob> chi ${ }^{2}$ (or p-value) of 0.7183 (attachment). The $p$-value $>0.05$, so it can be concluded gravity model is free from autocorrelation.

Based on the results of the fourth test of this assumption in the regression analysis concluded there was no violation of the assumptions in the regression model. It can be concluded that the regression function is obtained from the calculation of estimators with the method of Ordinary Least Squares (OLS) regression coefficient is Best Linear Unbiased Estimator (BLUE).

\section{Regression Analysis of Factors Affecting Bilateral Trade between Indonesia and Yemen During the Period 1990-2015}

In this section, will be reviewed any factors that significantly affect the bilateral trade between the Yemen for the period 1990-2015. To see the effect of independent variables significantly or not toward the dependent variable, the results of the regression analysis seen the value of $p>$ [t]. If the value of $p>[t]$ of less than 0.05 , then the independent variables significantly influence the dependent variable (and vice versa). Analysis of the influence of independent variables in the regression results of the gravity model of the factors affecting bilateral trade between Indonesia and Yemen, described as follows: 


\section{Table 2. Regression Analysis of Factors Affecting Bilateral Trade Value Indonesia -Yemen During the Period 1990-2015}

Linear regression

Number of obs
F $(3,18)$
Prob $>$ F
R-squared
Root MSE

$=$

$=$

$=$

$=$

0.8320

Root MSE

.24142

\begin{tabular}{|c|c|c|c|c|c|c|}
\hline In_total_trade & Coef. & $\begin{array}{l}\text { Robust HC2 } \\
\text { Std. Err. }\end{array}$ & t & $P>|t|$ & \multicolumn{2}{|c|}{ [95\% Conf. Interval] } \\
\hline ln_gdp_indo & .1503926 & .1380659 & 1.09 & 0.290 & -.1396731 & .4404583 \\
\hline ln_gdp_yaman & .353991 & .1183423 & 2.99 & 0.008 & .1053631 & .6026189 \\
\hline yemeni_instability & -.3156616 & .1855177 & -1.70 & 0.106 & -.7054198 & .0740966 \\
\hline indonesia_instability & -.1201589 & .0545657 & -2.20 & 0.041 & -.2347972 & -.0055207 \\
\hline ri_embassy & 1.286901 & .0959599 & 13.41 & 0.000 & 1.085297 & 1.488505 \\
\hline _cons & -8.970981 & 1.903834 & -4.71 & 0.000 & -12.97079 & -4.971173 \\
\hline
\end{tabular}

Source: Adapted by the author

\section{Indonesia's GDP}

Indonesia's GDP showed massive size of the Indonesian economy. The magnitude of Indonesia's GDP is expected to have a positive influence and real (significant) to the value of bilateral trade between the Yemen. If an increase in GDP of Indonesia, the value of bilateral trade between the Yemen is expected to rise as well, ceteris paribus. Regression analysis showed Indonesia's GDP variable coefficients are not significantly positive impact on the value of bilateral trade between the Yemen. That is, the results of the regression analysis concludes that the GDP of Indonesia does not have enough evidence to say that Indonesia's GDP significantly affect the value of bilateral trade between the Yemen.

\section{GDP Yemen}

Yemen's GDP showed massive size of the economy of Yemen. Magnitude of Yemen's GDP is expected to have a positive influence and real (significant) to the value of bilateral trade between the Yemen. If an increase in GDP of Yemen, the value of bilateral trade between the Yemen is expected to rise as well, ceteris paribus. Regression analysis showed GDP of Yemen coefficient significantly positive impact on the value of bilateral trade between the Yemen. This means consistent with the hypothesis.

Indonesia's GDP variable coefficient value of 0.353991 means that if there is an increase of 1 percent of Indonesia's GDP, the value of trade between Indonesia and Yemen will increase by 0.353991 percent, ceteris paribus. This means that these variables should also become a consideration for the Government of Indonesia and Yemen to boost bilateral trade.

\section{Uncertainty Political and Security in Yemen}

Political uncertainty and security in Yemen shows the risk level overview of the political situation and security of Yemen. Political uncertainty and security in Yemen are expected to negatively and significantly on the value of bilateral trade between the Yemen. Incase of political uncertainty and security in Yemen, the bilateral trade value between Indonesia and Yemen are expected to decline, ceteris paribus.

Regression analysis showed variable coefficients political uncertainty and security in Yemen are not significantly negatively impact the value of bilateral trade between the Yemen. 
Similar to the case of Indonesia's GDP, then based on the results of the regression analysis can be concluded that the political uncertainty and security in Yemen do not have enough evidence to say that the political uncertainty and security in Yemen significantly affect the value of bilateral trade between the Yemen.

\section{Uncertainty Political and Security in Indonesia}

Political uncertainty and security in Indonesia showed the risk level overview of the political and security situation in Indonesia. Political uncertainty and security in Indonesia is expected to give a negative effect and the real against the value of bilateral trade between the Yemen. In case of political uncertainty and security in Indonesia, the bilateral trade value between Indonesia and Yemen are expected to decline, ceteris paribus.

Regression analysis showed variable coefficients political uncertainty and security in Indonesia significantly negatively impact the value of bilateral trade between the Yemen. This means consistent with the hypothesis. The coefficient of variable political uncertainty and security in Indonesia for -0.1201589 means that in case of political uncertainty and security in Indonesia by 1 percent, then the value of trade between Indonesia and Yemen will be decreased by 0.1201589 percent, ceteris paribus. This means that the independent variable should also become a consideration for the Government of Indonesia and Yemen in enhancing bilateral trade.

\section{The presence of Indonesian Representative in the Republic of Yemen}

The existence of Indonesian Representative in the Republic of Yemen indicates the status Embassy in Sana'a in the Republic of Yemen is a country of accreditation. Theexistence of Indonesian Representative in the Republic of Yemen is expected to have a positive influence and significant effect on the value of bilateral trade between the Yemen. If there Indonesia Representative in the Republic of Yemen, the bilateral trade value between Indonesia and Yemen are expected to increase, ceteris paribus (and vice versa).

The regression analysis showed the presence of variable Indonesian Representative in the Republic of Yemen significantly positive impact on the value of bilateral trade between the Yemen. This means consistent with the hypothesis. The coefficient of the variable presence of Indonesian Representative in the Republic of Yemen amounted to 1.286901, meaning if an increasing number of Indonesian Representative in the Republic of Yemen by1 percent, then the value of trade between Indonesia and Yemen will increase by 1.286901 percent, ceteris paribus. This variable should also become a consideration for the Government of Indonesia and Yemen in enhancing bilateral trade relations.

\section{Conclusions And Recommendations}

The situation of political uncertainty, security, and economy in Yemen continues to this day. As a result, Yemen's economic relations with other countries (mainly as a trading partner and investor) has decreased lately. In trade relations between Indonesia and Yemen, during the period 1990-2015, the trade relations between the two countries fluctuated. In a report released a few Embassy in Sana'a explained that apparently the situation of political uncertainty, security and economic development in Yemen have negative impact on trade relations between Indonesia and Yemen.

Based on the results of hypothesis testing and the accuracy of the model (Goodness of Fit) using a statistical test criteria that the coefficient of determination $\mathrm{R}^{2}$ and $t$-test. T-test results find the variables that significantly is the GDP of Yemen, political uncertainty and security situation in Indonesia, as well as the presence of the Indonesian Embassy in Sana'a in Yemen. Meanwhile, Indonesia's GDP variable and uncertain political and security situation in Yemen has no significant effect on bilateral trade between Indonesia and Yemen. In addition, the coefficient $R^{2}$ indicates that the independent variables in the model is able to explain the 
variation in bilateral trade between the Yemen.

Furthermore, after testing the assumptions in the multiple regression analysis by normality test, homoskedasticity, multicollinearity test, autocorrelation test and concluded there was no violation of the assumptions in the regression model. Thus, it can be concluded that the regression function is obtained from the calculation of estimators with the method of Ordinary Least Squares (OLS) regression coefficient is Best Linear Unbiased Estimator (BLUE).

The analysis results of the influence of independent variables in the regression model of the gravitational factors that affect bilateral trade between the Yemeni find that there are three independent variables that significantly influence such GDP Yemen, political uncertainty and security in Indonesia, as well as the presence of Indonesian Representative in the Republic of Yemen. These three variables are consistent with the hypothesis of this study and should be the focus of consideration for Indonesia and Yemen in enhancing bilateraltrade relations. While other independent variables namely Indonesia's GDP and political uncertainty and security in Yemen, based on the conclusions statistically, the two independent variables do not yet have enough evidence to say that the GDP of Indonesia and political uncertainty and security in Yemen significantly affect bilateral trade between the Yemen.

From the results of empirical studies, it can be presented that when there are a numberof disturbance variables which influence such as the economic downturn in Yemen, political uncertainty and security in Indonesia, as well as the non-existence of Indonesian Representative in the Republic of Yemen, then generally bilateral trade relationship should show direction upward trend. This is reflected in the development of trade relations between Indonesia and Yemen over the past 25 years.

Claims of several reports released Embassy in Sana'a that the situation of political uncertainty, security and economic development in the Republic of Yemen have negative impact on trade relations between Indonesia and Yemen in this regard is not relevant. As explained earlier, political uncertainty and security in Yemen do not have enough evidence toexplain that political uncertainty and security in Yemen significant effect on the value of bilateral trade between the Yemen. However, based on the results of the regression analysis, precisely Yemen's GDP that significantly affect the bilateral trade relations between Indonesia and Yemen. That is weakening the economy in Yemen significantly negative impact on the value of bilateral trade between the Yemen.

In the coefficient of determination $\mathrm{R}^{2}$, found that 16.8 percent is explained by confounding variables that are not put into the equation. In this regard, based on input from some of the results of internal reports released by the Ministry of Foreign Affairs (cqEmbassy in Sana'a) explained that there are a number of obstacles and challenges in improving trade relations between Indonesia and Yemen, among others, are: Indonesia's exports to Yemen is still through the third party (Dubai or Singapore), corrupt practices in Yemen and the still strong influence of traditional culture of the tribes, promotional materials and budget limitations Embassy in Sana'a, and is still a tendency establish business contacts by way of cash and carry.

Taking into consideration a number of challenges and constraints as well as the resultsof empirical conclusions above, the author tries to formulate some economic diplomacy policy advice to the Government of Indonesia (in this case the trade diplomacy) in order to increase bilateral trade between Indonesia and Yemen. Policy advice trade diplomacy is the subjective views of the author, interviews (informal) with representatives of the staff of the Embassy Sana'a, as well as some of the reports released by the Embassy in Sana'a. As for suggestions that trade diplomacy policies are as follows:

1. Implementation of the Joint Commission Meeting III are scheduled for the year 2012 can not be implemented. In accordance with the change or order implementation 
of LCS, Indonesia is going to be the host of LCS III. SKB is one important forum containers in diplomatic relations between Indonesia and Yemen in addressing issues of common concern and bilateral cooperation in various fields.

2. Efforts exploratory Indonesia - Yemen Free Trade Agreement (FTA) or a Preferential Trade Agreement (PTA). The Republic of Yemen has been a member of all 160 WTO Ministerial Conference on 9th December 4, 2013 in Bali. And on April 28, 2014, the Yemeni Parliament has ratified the WTO accession protocol. After that, the Republic of Yemen is expected to restructure the regulations particularly with regard to free trade.

3. MoU or economic agreement would need to be followed in the future: a) The establishment of non-profit organizations such as the Indonesia - Yemen Business Council (IYBC) and Indonesia - Yemen Eminent Persons Group (IYEPG); and b) AirTransportation Agreement between Indonesia and Yemen.

4. It should be pursued (or encouraged) the delivery of merchandise Indonesia - Yemen directly. Embassy in Sana'a assess port in Hadramout region is one of the port's current potential in Yemen. Currently, many goods and commodities Indonesia to Yemen through the state or third parties such as Dubai, Jeddah and Singapore.

5. If the situation in Yemen has returned favorable, presumably the Air Transport Agreement between Indonesia and Yemen are yet to be signed between the two countries (but already initialed) can be followed in the future. Agreement on air transportation agreement is expected to improve the Trade, Tourism, and Investment (TTI) between the two countries.

6. Need to do an assessment and evaluation of Indonesia - Yemeni visa exemption. Visaexemption is expected to encourage people to people contact between the two countries, and in turn helped increase the flow of trade between the two countries. As an illustration, by March 2016, the Government of Indonesia has a visa-free stay for 30 days to 169 friendly countries (Adityo, 2016). However, the policy of granting visas should be passed prior to the bilateral talks between Indonesia and Yemen basedon the principle of reciprocity. For information, until now the Republic of Yemendoes not provide visa exemption to citizens who visit Yemen.

7. Using the momentum of a positive relationship between Indonesia and Yemen. In addition to its economic potential, in the socio-cultural field between the two countries have a fairly strong emotional attachment in terms of both historical and from the large number of Indonesian citizens of Yemeni Arab descent in Indonesia. Moreover, in the political, Yemen was the first Arab country (1948), which recognizes the independence of Indonesia after Egypt and in the bilateral relationship between Yemen government fully supports the Republic of Indonesia (NKRI) and almost always supported the candidacy of Indonesia in various international forums. The Yemeni government has always considered Indonesia as a brotherly country.

Furthermore, the position of the Government of Yemen in an effort to cultivate partnerships with Islamic countries have in common with Indonesia in addition to the historical relationship that has been forged since several centuries ago could be al-ardhiyah al-musytarakah (common ground) for the improvement of political relations between the two countries to flourish all other fields. This certainly is a great asset for Indonesia to continue for improving relations in all fields.

\section{References}

Adityo, W. . (2016). Inilah Daftar Negara yang Bebas Visa Berkunjung ke Indonesia. 
Bergstrand, J. H. (1985). The Gravity Equation in International Trade: Some Microeconomic Foundations and Empirical Evidence. The Review of Economics and Statistics, 67(3). https://doi.org/10.2307/1925976

Hanke, J. E., Wichem, D. W., \& Reitsch, A. G. (2003). Peramalan Bisnis (7th ed.). Prenhalindo.

Rose, A. K. (2007). The foreign service and foreign trade: Embassies as export promotion. World Economy, 30(1). https://doi.org/10.1111/j.1467-9701.2007.00870.x

Sarwoko. (2009). Perdagangan Bilateral Antara Indonesia dengan Negara-Negara Partner Dagang Utama dengan Menggunakan Model Gravitasi. Jurnal IImiah MTG, 2(1).

Tinbergen, J. (1962). Shaping the World Economy - Suggestions for an International Economic Policy (Twentieth).

Yakop, M., \& van Bergeijk, P. A. G. (2011). The Weight of Economic and Commercial Diplomacy. SSRN Electronic Journal. https://doi.org/10.2139/ssrn.1469137

Yuniarti, D. (2007). Analisis Determinan Perdagangan Bilateral Indonesia Pendekatan Gravity Model. Economic Journal of Emerging Markets, 12(2). 